\title{
Mongolia and the Nuclear Age
}

\author{
By J.Enkhsaikhan (Mongolia)
}

\begin{abstract}
$\mathrm{T}$ is XXI century is a nuclear century since our security, development and progress depends to a certain extent on how we humans are dealing with the nuclear issues. Mongolia, as member of the world family of nations, and especially sandwiched between two nuclear-weapon powers, is directly affected by nuclear issues. There is no escape. We have to make a choice either to be passively affected by the perils of nuclear age or play an active role, to the extent possible, in shaping our own future. That depends to a great extent on us, Mongolians.

Nuclear issues could be addressed from the following angles: national security, security of the people's health and environment and energy security.
\end{abstract}

\section{A. Nuclear-weapon-free status of Mongolia ${ }^{1}$}

Mongolia's nuclear-weapon free status (NWFS), institutionalization of which is yet to be achieved, is based on the country's policy of ensuring its security primarily by political and legal means. In this case the status would mean that all nuclear-weapon States, especially its two immediate neighbors, would not only respect the status and legally conmit not use or threaten to use nuclear weapons against Mongolia, but also pledge not to involve Mongolia and its territory in their nuclear calculations and policies. As the developing dispute in Eastern Europe clearly demonstrates, territories of third States could be used to involve them

${ }^{1}$ The National Security Concept of Mongolia, adopted in June 1994 by the State Great Hural (parliament) addressing the ways and means of ensuring the security of existence of Mongolia has underlined the need to ensure the nuclear-weapon-free status of Mongolia at the international level and make it an important element of strengthening the country's security by political means. In February 2000 the parliament adopted the Law on Mongolia's nuclear-weapon-free status that defines the status and regulates the legal consequences of all the related activities. 
in "power politics" of the great powers. Thus U.S. plan to base parts of a missile-defense system in the Czech Republic and Poland "to combat potential new threats from nations seeking nuclear weapons, like Iran" has prompted Russia to take a tougher line in its relations with the U.S. and suspend its participation in a key European arms control treaty that governs deployment of troops on the continent. ${ }^{2}$ That is why the latter cormitment is very important for Mongolia in order not to be involved in great power rivalry, but also for ensuring nuclear stability and predictability in the region, since any change in Mongolia's policy could affect the balance of power in the region.

The policy of institutionalizing its NWFS is also breaking new ground in theory and practice of creation of nuclear-weapon-free zones (NWFZ) . The General Assembly of the United Nations in 1998 welcomed Mongolia's initiative and policy and called upon all member States to work with it in consolidating and strengthening its security and NWFS, while the five nuclear-weapon States (the P-5, that happen to be the five permanent members of the United Nations Security Council) have made in 2000 a joint statement providing negative and positive security assurances to Mongolia. At present the policy needs to be pursued to expand the P-5 political declaration and turn it into a legally binding commitment. When institutionalized, Mongolia would be the first single-State NWFZ in international relations with duly provided security assurances from the P-5. So far no individual state has been able to acquire such a status, while there are over a dozen States that could benefit from such a precedent and ensure their security through single-State NWFZ status as part of the regional security arrangement.

On the other hand, single-State NWFZ status could be an interim measure for States that are currently under nuclear umbrella to abandon it as a NWFZ (with the security assurances provided in such a case by nuclear-weapon States) and negotiate its status as part of a regional NWFZ. Thus in the case of Northeast Asian NWFZ, Japan and South Korea would need to abandon U.S. nuclear umbrella and level the playing field for negotiating the regional NWFZ. Interim single-State NWFZ status could come in handy for them.

For Mongolia itself, institutionalization of its special status in the form of a multilateral agreement with legally binding security assurances

\footnotetext{
${ }^{2}$ Thus Russia has declared that it would halt inspections and verifications of its military sites by NATO countries and would no longer limit the number of its conventional weapons (i.e. limitations on the deployment of tanks, armored combat vehicles, artillery and attack helicopters and combat aircraft.
} 
would in fact be tantamount to intemational recognition of its neutrality policy pursued since early 1990s and reflected in its national security concept in regard to future possible Sino-Russian disputes that do not directly affect Mbngolia's vital national interests. This neutrality policy could, with the support of the internationally recognized NWFS, be extended to Russian and Chinese disputes with other Asian powers or among them. There is already a wide political pre-requisite for such recognition which is reflected in United Nations General Assembly resolution 53/77 D entitled "Mongolia's international security and nuclear-weapon-free status". The General Assembly thus has welcomed "Mongolia's active and positive role in developing peaceful, friendly and mutually beneficial relations with the States of the region", has security and stability" . The Assembly has reiterated its support for Mongolia's policy in 2000, 2002, 2004 and 2006. Therefore institutionalization of the status would in fact be recognition and acceptance of broadening further endorsed and expressed support of its "good-neighborly and balanced relationship with its neighbors" as an important element of strengthening regional peace, its neutrality policy. Institutionalization of the status could serve as a legal and political leverage in addressing the issue of the silent nuclear threat.

\section{B. Silent nuclear threats}

The nuclear age holds enormous promises as well as hidden perils. In the past half century the world witnessed escalation of the dangerous nuclear arms race and a race to perfect nuclear weapons through nuclear weapons tests. Out of 2036 registered nuclear weapon tests conducted in the world until today, 760 (or about 27 percent of all the tests) have been conducted by the two neighbors mostly in the vicinity of Mongolia, ${ }^{3}$ health and environmental consequences of which have yet to be studied. We still do not know what the past holds for our children and grandchildren.

The future is not rosy as well. Acceleration of the global warming demands innovative approaches to the issues of energy production and use. Though renewable power like wind and solar, as well as decentralized power generators are giving some answers, they are not enough to adequately address the issue. That is why more and more people are linking their hope with the nuclear energy since nuclear power plants do not release greenhouse gases (GHGs) .

${ }^{3}$ Thus the Soviet Union conducted 207 atmospheric and 508 underground tests, while China - 23 atmospheric and 17 underground. 
Until the 1986 Chernobyl nuclear power plant accident there was a tendency of increase in the number of nuclear power stations despite the unresolved issues of nuclear wastes. After the Chernobyl accident this tendency slowed down for almost two decades. Now there is again a growing interest in and demand for nuclear power because of the growing greenhouse effect of increased use of fossil fuel. According to IAEA's 2004 report, the 440 nuclear power reactors operating in the world were producing $16 \%$ of world's electricity, with 26 more reactors under construction, including 18 in Asia. Entry into force of the Kyoto Protocol is also making States parties to tum more to nuclear energy.

The role of nuclear energy is increasing especially in Northeast Asia. Thus if by mid 1990s the share of nuclear energy in the Republic of Korea was 36\%, in Taiwan $28.8 \%$ and in Japan 33.8\%, it is estimated that by 2010 almost $1 / 2$ of the world's nuclear energy would be produced and consumed in this region. Chinese share in nuclear energy production is increasing. ${ }^{4}$ Along with production of nuclear energy these countries are facing the dilemma of temporary and/or permanent disposal of nuclear wastes, especially high level radiological wastes (HLW), the amount of which is increasing with each passing year ${ }^{5}$. In short, the question of disposal of nuclear wastes ${ }^{6}$ is one of the most challenging

${ }^{4}$ It is estimated that in the next ten years China might build up to 30 new reactors, Japan 13 and the Republic of Korea - 10. Russian is planning to double its nuclear power output by 2020, while China is planning to double it. India plans to increase it nuclear power output by 8 fold by year 2022 .

${ }^{5}$ There is a common belief that the vast territories of Siberia, Australian outback, the Gobi Desert and Canadian Shield could be used to deposit permanently muclear wastes. Many scientific researches are being done and intemational conferences held on this issue. Thus just recently, on 1922 June an International Conference on Management of Spent Fuel from Nuclear Power Reactors was held in Viemna under the auspices of IAFA, in which nearly 200 participants and observers from 41 countries and intemational organizations shared information, lessons and experiences.

${ }^{6}$ See Dr. Helen Caldicott's article "Nuclear Power Isn't Clean; Its Dangerous" which demonstrates how nuclear waste threatens global health since the toxicity of many elements in the waste is long-lived. Thus Strontium 90 remains radioactive for 600 years. Concentrating in the food chain, it emulates the mineral calcium. Contaminated milk enters the body, where strontium 90 concentrates in bones and lactating breasts later to cause bone cancer, leukemia and breast cancer. Babies and children are 10 to 20 times more susceptible to the carcinogenic effects of radiation than adults. Plutonium, the most significant element in nuclear waste, is so carcinogenic that hypothetically half a kilo evenly distributed could cause cancer in everyone on Earth. Lasting for half a million years, it enters the booky through the lungs where it is known to cause cancer. It mimics iron in the body, migrating to bones, where it can induce bone cancer or leukemia, and to the liver, where it can cause primary liver cancer. It crosses the placenta into the embryo and, like the drug thalidomide, causes gross birth deformities. Plutonium has a predilection for the testicles, where it induces genetic mutations in the sperm of humans and other animals that are passed on from generation to generation (see http://healthandenergy.com/ nuclear_dangers.htm). 
nuclear issues facing not only the intemational scientific commuity but the world in general.

Mongolia does not have nuclear reactors and thus is not a beneficiary of nuclear technology. However, despite that she runs the risk of becoming sandwiched between enormous nuclear waste repositories ${ }^{8}$ with all the ensuing potential long-lasting health and environmental consequences. This is because our neighbors not only have nuclear waste repositories on their territories that are adjacent to Mongolia, but, in the case of Russia in 2001 it has adopted legislation encouraging import of nuclear wastes from other countries ${ }^{10}$. Thus it is estimated that in the 10 years since adoption of the 2001 legislation, Russia could import 1020.000 tons of nuclear waste, most of which is expected to be stored at the storage facility in Zheleznogorsk (Krasnoyarsk region) ${ }^{11}$. There are even talks that the decommissioned uranium mines in Krasnokamensk, to the east of the Lake Baikal (not far from Mongolia) , might be used as a site of final (meaning etemal) disposal of nuclear wastes. Moreover, according to fuel repatriation program agreed between Russia and U.S. in May 2004 as part of Global Threat Reduction Initiative, a dozen countries have become eligible to receive financial and technical assistance from the U.S. to ship their fresh and spent research reactor fuel, originally obtained from the Soviet Union/Russia back to Russia for "safekeeping and reprocessing into safer materials". Where all the spent fuel ends up in Russia is anybooly's guess.

The above events cannot be ignored by Mongolia simply because they are taking place in another country or that importing whatever waste is an internal affair of that country. However the 6.8 magnitude

\footnotetext{
${ }^{7}$ The 440 nuclear reactors have produced about 280.000 metric tons of spent nuclear fuel (over 12.000 metric tons per year).

${ }^{8}$ It is believed that nuclear waste remains hazardous for tens of thousands of years and that the only way to get rid of it is to put it in containers and bury it deep underground (and pray tat geological shifts do not disturb it) .

${ }^{9}$ No reliable information in regard to China is available from Chinese or other sources

${ }^{10}$ Meaning importing not only nuclear waste from Soviet-built nuclear power stations but also from other nuclear reactors. Russian official reasoning for importing nuclear waste are as follows: to be able to upgrade Russia's nuclear storage, clean up heavily contaminated land and expand its nuclear processing operations at Mayak nuclear complex in the Ural mountains.

${ }^{11}$ Other known nuclear waste repositories are in Chelyabinsk-65"Mayak" near Ozersk and Novaya Zemlya (Northern Archangelsk) .
} 
earthquake that hit Japan a few weeks ago has vividly demonstrated how radioactive elements could be released into the air (and in Japan's case into ocean) by nuclear power plants.

We cannot blame our neighbors for their policies and choices. It is their sovereign choice as long as it does not now nor in the long run adversely affects Mongolian people's health and the environment as described in the national security concept (paras. 49.1 and 53.2) . Therefore it is up to us Mongolians to closely examine either on our own or together with the neighbor (s) the possible long-term effects and consequences of having huge nuclear waste sites almost at our doorsteps.

Data or information is scarce to analyze china's situation and policy with regard to nuclear wastes. What is known is that not only China's nuclear industry is producing nuclear waste, but that it has on a number of occasions discussed the possibility of importing nuclear waste from other countries to store in China, possibly in Gansu province (that borders on Mongolia) or even in the Gobi desert. Since Russia and China, as recognized nuclear-weapon states are not required to conclude special agreements with IAEA on strict and rigorous inspection of their nuclear facilities, the question of safety of their nuclear facilities and repositories acquire special significance for Mongolia. Therefore we cannot afford to be a passive observer of these events and ominous trends. Lately, Kazakhstan, following the examples of Russia, is openly expressing interest, on commercial basis, to store on its territory low or intermediatelevel nuclear waste from other countries. Would that mean that Mongolia would have additional nuclear waste sites on its westem doorsteps?

Mongolian experts and nuclear scientists should closely follow these and related events, make analysis of the situation from the standpoint of Mongolian immediate and long-term interests and make concrete proposals to the National Security Council, Parliament and Government of Mongolia on ways to deflect the danger, on how to engage its neighbors, other interested states and international organizations in addressing.

\section{Energy security}

As it has been pointed out earlier in this paper, the nuclear reaction provides enormous energy that is increasingly being used to generate electricity. In France, for example, up to $80 \%$ of electricity is generated by nuclear power plants, while in Japan - almost 1/3. Though Mongolia's 
energy needs are not enormous, nevertheless it is increasing, while the country depends highly on oil imports from Russia. That is why some Mongolians, including some nuclear experts, propose building a small or medium size nuclear power plant that could resolve in the main the country's energy needs. They say that Mongolia has enormous reserves of uranium ores, some of which are included in the list of strategically important mines ${ }^{12}$. Some feasibility studies on constructing nuclear power station (s) have already been undertaken. What is needed now is to move beyond studies and take a decision on the best way of utilizing the uranium mines and building nuclear power station(s) to satisfy the increasing needs in electricity as well as reduce the dependence on foreign energy supply. In order to do that a state policy on promoting nuclear science and energy needs to be elaborated. Also the comprehensive policy for national development, currently under discussion, should address one way or another this issue. If Mongolia decides to develop nuclear energy, the International Atomic Energy Agency (IAEA) could provide appropriate assistance3 by its statute as well as by Article IV of the Treaty on the Non-Proliferation of Nuclear Weapons (NPT).$^{13}$

Bearing the above in mind, I would recommend the following as concrete steps to address the challenges of the nuclear age:

1 intensify our efforts to conclude a trilateral agreement with the two immediate neighbors institutionalizing Mongolia's NWFS and acquire legally binding security assurances from them and other nuclearweapon States that they would respect Mongolia's neutrality policy with respect to future possible disputes among nuclear and other powers;

2 make Mongolia's NWFS integral part of the emerging international network of NWFZs;

\footnotetext{
${ }^{12}$ Mardai, Dornod and Gurvan Bulag.

${ }^{13}$ Article IV of NPT reads as follows: "(1) Noting in this Treaty shall be interpreted as affecting the inalienable right of all Parties to the Treaty to develop research, production and use of nuclear energy for peaceful purposes without discrimination and in conformity with Articles I and II of this Treaty. (2) All the Parties to the Treaty undertake to facilitate, and have the right to participate in, the fullest possible exchange of equipment, materials and scientific and technological information for the peaceful uses of nuclear energy. Parties to the Treaty in a position to do so shall also co-operate in contributing alone or together with other States or intemational organizations to the further development of the applications of nuclear energy for peaceful punposes, especially in the territories of non-nuclear-weapon States Party to the Treaty, with due consideration for the needs of the developing areas of the world."
} 
3. make serious health and environmental assessment of the legacies of over 700 nuclear-weapon tests in the vicinity of Mongolia (together with the neighbors, other interested countries, the WHO, IAEA and others);

4 undertake, together with the neighboring countries and the IAFA, a study on possible environmental and health effects of nuclear waste repositories of neighboring countries and consider its results at the National Security Council and parliament of Mongolia;

5. develop and adopt national policy with regard to nuclear issues, including future uses of uranium and nuclear energy;

6. if a decision is taken to develop nuclear energy by constructing nuclear reactors, make the best use of IAEA advise to make use of the safest technology.

Ulaanbaatar, 21 August, 2007 